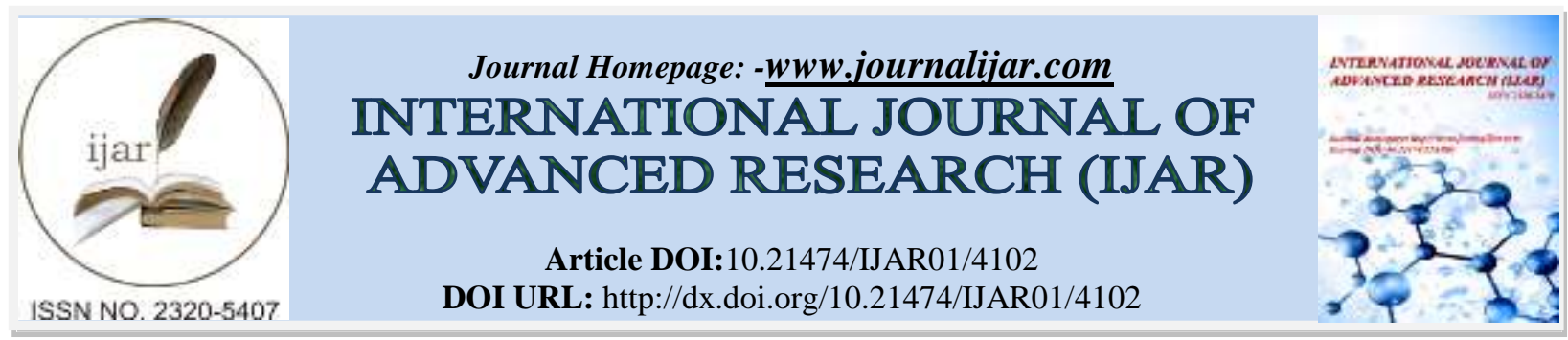

RESEARCH ARTICLE

\title{
ATTITUDE AND PERCEPTION OF TEENAGE MOTHERS REGARDING TEENAGE PREGNANCY.
}

Mrs. Sonam Tomar ${ }^{1}$, Mrs. Kavitha Mole PJ ${ }^{2}$ and Prof. Dr. N V Munninarayanappa ${ }^{3}$.

1. M.Sc. Nursing Final Year Student, Teerthanker Mahaveer College Of Nursing, Teerthanker Mahaveer University, Moradabad.

2. Professor, Teerthanker Mahaveer College of Nursing, Teerthanker Mahaveer University.

3. Principal, Teerthanker Mahaveer College of Nursing, Teerthanker Mahaveer University.

\section{Manuscript Info}

\section{Manuscript History}

Received: 08 March 2017

Final Accepted: 10 April 2017

Published: May 2017

Key words:-

Attitude, perception, experience, teenage pregnancy, teenage mother.

\section{Abstract}

Introduction: Teenage pregnancy is pregnancy in females under the age of 20 years. Every day in developing countries 20,000 girls which comes under aged 18 years give births. This amounts to 7.3 million birth per year. Teenage pregnancy is risk factor for drop out the school, unemployment, HIV/AIDS, STD, preterm baby, psychological distress, abortion. Hence, a narrative review was carried out to explore the attitude and perception of teenage mothers regarding teenage pregnancy. Methods: Database searched were EBSCO, DELNET, PubMed and journals. The scholarly articles and references list of primary articles. Online database key word used such as a qualitative study, attitude and perception, teenage mothers, teenage pregnancy and experience. 18 articles searched by database in which 6 articles selected for this review under the following eligibility criteria. Qualitative studies $(n=6)$ were identified which based on attitude and perception of teenage mothers regarding teenage pregnancy. Result: Out of 6 articles 5 articles shown negative attitude of teenage mothers regarding teenage pregnancy(dropping school, no continuation of education ahead, chances of STD and HIV Infection and low socioeconomic status). One study shown positive perception regarding teenage pregnancy (receiving attention, love, care from her family, husband and in-laws, she feel independent). Conclusion: Teenage pregnancy is a socioeconomic challenge and an important health problems. Teenage pregnancy is risk factors for HIV and other STD infections, preterm birth, abortion, psychological distress, nutritional deficiencies from poor eating habits in adolescents and teenage mothers felt difficulty to travel. Teenagers need motivation and advice regarding using of contraceptive methods and teenage pregnancy.

Copy Right, IJAR, 2016,. All rights reserved.

\section{Introduction:-}

Teenage pregnancy is defined as a teenaged or under aged girl (usually within the ages of 13-19) becoming pregnant. A girl can become pregnant when ovulation period has started in females and after her first menstrual period. Teenage girls who is well nourished in that condition menarche take place around the age of 12 or 13 years. 
Pregnant teenagers face many problems regarding obstetrical issues. Teenage pregnant who is at the age of 15 years they are less physically developed. (Wikipedia).

Teenage pregnancy occurs when partner did not use reliable contraceptive methods and when poor coitus communication is present between partners. Mostly teenage mothers have careless attitude towards sex and fear of using contraceptive methods. If teenage girls have low education and they belongs to poor family that it can become a reason of teenage pregnancy. (Kanku.T, 2009)

Some studies indicated that teenagers are sexually active in their puberty life. During puberty time they are facing many challenges such as females are having menstruation and in boys are having wet dreams and during this period they are active to make sexual relationship and they may do it even using of safety methods. Some adolescent's are having the perception that teenage pregnancy is not good for their health because it cause many diseases which can threat to their life. Teenage pregnancy can be a barrier to achieve goals in education field. Teenage mothers mostly live in poverty, lacks to get prenatal care, gains less weight during pregnancy. These all factors are associated with poor birth results. Few adolescents from rural area perceived that their community did not allowed them to become pregnant under the age of 20 years. It is illegal according to their community. (S Richter 2005)

Some teenagers perceived positively about teenage pregnancy that they get become independent, receive love, attention and recognition. They able to maintain the good relationships with their partners and they proved that they are capable for having a child and become closer to the family. Adolescent parents shows positive attitude regarding teenage pregnancy that after having baby they become strong, stopped all doing stupid things ,they more grown up with growing baby, and developed more ability to manage the time. Some adolescent had negative attitude towards teenage pregnancy. They think that those teenage mothers are unable to solve their problems and unable to take care of herself and her baby also and they support to abortion (Herman, 2008).

A perception of teenage mothers regarding teenage pregnancy that they did not get any sex education by their parents therefore they got pregnant. If they got education regarding sex from their parents then this mistake did not happened and they did not face these problems (S Richter, 2005).

Teenage pregnancy can be prevented by high education level. Some teenagers express their perception that we need more information to prevent teenage pregnancy, they need to know about the good contraceptive methods which can prevent the teenage pregnancy and they want to know about the diseases which are caused by teenage pregnancy; these all information increase the knowledge of teenagers and prevent the teenage pregnancy (kanku.T,2009).

Everyday in developing countries; 20,000 girls under age 18 give birth. This total amount is 7.3 million births a year. If all pregnancy included among them adolescent pregnancy is much higher. (Wikipedia)

Teenage pregnancy rate is high in India that is 62 pregnant per 1000 women in the age group of 15-19 years. Statistics show that teenage pregnancy is higher in India other than other countries like in US were 42 per 1000 women and in UK 24 per 1000 women a (According to a united nations population fund report in 2013).

The aim of these studies was to explore the attitude and perception of teenage mothers regarding teenage pregnancy among antenatal mothers, unmarried girl and postnatal mothers who admitted in postnatal ward.

\section{Materials Methods:-}

Reviews of literatures searched from databases which are related to the topic that is "Attitude and perception of teenage mothers regarding teenage pregnancy. The review focused on the period 2005-2015. 18 articles searched out of that16 articles were from EBSCO, DELNET, Pub Med database and 2articles searched through Journal of health population \& nutrition and Iranian journal of nursing and midwifery research. Key words searched included attitude, perception, teenage pregnancy, teenage mothers, experience and a qualitative study. From this 18 reviews 6 articles I have removed because those articles did not give proper about attitude and perception of teenage mothers regarding teenage pregnancy. From the remaining 12 articles I have removed 2 articles because they were not full text articles.10 full text articles assessed for eligibility from that 4 full text articles removed because these 4 articles 
were quantitative and did not explained clearly about the attitude and perception of teenage mothers regarding teenage pregnancy. Finally in this review for qualitative synthesis 6 articles selected. (See in figure 1)

In all studies the data was collected by in-depth interview in which semi-structured open ended questionnaire was used. The duration of interview was approximately 30-45 minutes. Assured anonymity and Confidentiality during the data collection. The written informed consent taken from the participants. Audio tape recorder used to collect the data and transcription of audio material to hardcopy, reading and listening of this material properly to become familiar with it. All the gathered informations were read carefully. Information were collected in local language then it translated into English. After that they formulated the themes, did the coding of the themes, and rearrangement of data under different themes. All articles which included in this review all were ethically approved.

\begin{tabular}{|l|}
\hline Id \\
en \\
tif \\
ic \\
at \\
io \\
$\mathrm{n}$ \\
\hline
\end{tabular}

\begin{tabular}{|l|}
\hline Sc \\
re \\
en \\
in \\
$\mathrm{g}$ \\
\hline
\end{tabular}

\begin{tabular}{|l|}
\hline El \\
ig \\
ib \\
ili \\
ty
\end{tabular}

\section{In}

$\mathrm{cl}$ ud ed

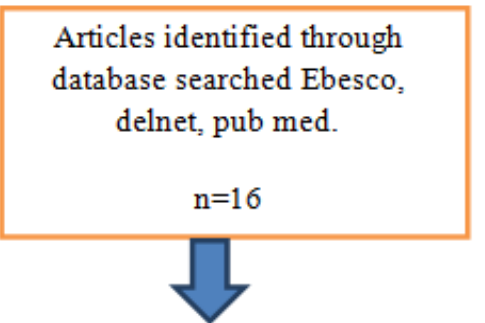

Articles after duplicates removed

$$
(\mathrm{n}=12)
$$

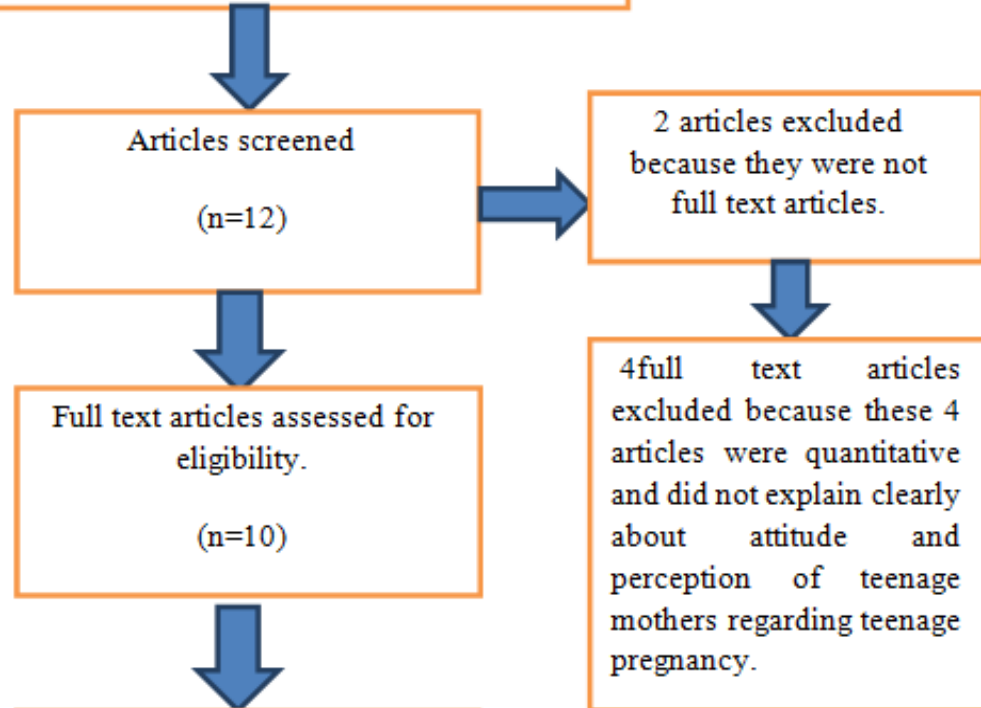

Studies included in qualitative synthesis

$$
(\mathrm{n}=6)
$$

Figure 1:- PRISMA Flow Chart. 
Table1:- Study characteristics: "Attitude and perception of teenage mothers regarding teenage pregnancy"

\begin{tabular}{|c|c|c|c|c|c|c|c|c|}
\hline $\begin{array}{l}\text { S.N } \\
\text { O }\end{array}$ & $\begin{array}{l}\text { AUTHOR/ } \\
\text { PROBLE } \\
\text { M } \\
\text { STATEM } \\
\text { ENT }\end{array}$ & $\begin{array}{l}\text { PLACE } \\
\text { OF } \\
\text { RESEAR } \\
\text { CH AND } \\
\text { YEAR }\end{array}$ & $\begin{array}{l}\text { OBJECTI } \\
\text { VES }\end{array}$ & $\begin{array}{l}\text { VAR } \\
\text { IAB } \\
\text { LES }\end{array}$ & $\begin{array}{l}\text { TOOLS/ } \\
\text { TECHNIQ } \\
\text { UES }\end{array}$ & $\begin{array}{l}\text { TIME } \\
\text { AND } \\
\text { DURAT } \\
\text { ION }\end{array}$ & OUTCOME & $\begin{array}{l}\text { REMARK } \\
\text { S }\end{array}$ \\
\hline 1. & $\begin{array}{l}\text { Swedish } \\
\text { teenager } \\
\text { perceptions } \\
\text { of teenage } \\
\text { pregnancy, } \\
\text { abortion, } \\
\text { sexual } \\
\text { behavior } \\
\text { and } \\
\text { contracepti } \\
\text { ve habits a } \\
\text { focus group } \\
\text { study } \\
\text { among } 17 \\
\text { year old } \\
\text { female high } \\
\text { school } \\
\text { students. } \\
\text { Maria } \\
\text { Ekstrand } \\
\text { and Tanja } \\
\text { Tyden }\end{array}$ & $\begin{array}{l}\text { Uppsala, } \\
\text { Sweden, } \\
2005 .\end{array}$ & $\begin{array}{l}\text { To } \\
\text { investigates } \\
\text { the teenage } \\
\text { perceptions } \\
\text { of teenage } \\
\text { pregnancy, } \\
\text { abortion, } \\
\text { sexual } \\
\text { behavior } \\
\text { and } \\
\text { contracepti } \\
\text { ves habits. }\end{array}$ & $\begin{array}{l}\text { Rese } \\
\text { arch } \\
\text { varia } \\
\text { ble- } \\
\text { Teen } \\
\text { agers } \\
\text { perce } \\
\text { ption } \\
\text { s of } \\
\text { teena } \\
\text { ge } \\
\text { pregn } \\
\text { ancy, } \\
\text { abort } \\
\text { ion, } \\
\text { sexua } \\
1 \\
\text { beha } \\
\text { vior } \\
\text { and } \\
\text { contr } \\
\text { acept } \\
\text { ive } \\
\text { habit } \\
\text { s. }\end{array}$ & $\begin{array}{l}\text { Focus group } \\
\text { interview }\end{array}$ & $\begin{array}{l}25-60 \\
\text { minutes }\end{array}$ & $\begin{array}{l}\text { The result of } \\
\text { this study } \\
\text { shown that } \\
\text { teenager's had } \\
\text { negative } \\
\text { attitudes } \\
\text { toward teenage } \\
\text { pregnancy and } \\
\text { supportive } \\
\text { attitudes } \\
\text { toward } \\
\text { abortion. Girls } \\
\text { were perceived } \\
\text { as more } \\
\text { obliged than } \\
\text { boys in taking } \\
\text { responsibility } \\
\text { for } \\
\text { contraceptive } \\
\text { uses and } \\
\text { avoidance of } \\
\text { pregnancy }\end{array}$ & $\begin{array}{l}\text { Carelessnes } \\
\text { s and } \\
\text { negligence } \\
\text { towards the } \\
\text { use of } \\
\text { contracepti } \\
\text { ve methods } \\
\text { and they } \\
\text { have } \\
\text { perception } \\
\text { regarding } \\
\text { hormonal } \\
\text { contracepti } \\
\text { ve methods } \\
\text { that it } \\
\text { caused side } \\
\text { effects due } \\
\text { to lack of } \\
\text { education } \\
\text { among } \\
\text { teenagers. }\end{array}$ \\
\hline 2 & $\begin{array}{l}\text { Perceptions } \\
\text { of rural } \\
\text { teenagers } \\
\text { on teenage } \\
\text { pregnancy. } \\
\text { Magdalena } \\
\text {.S . Richter }\end{array}$ & Feb 2005 & $\begin{array}{l}\text { To explore } \\
\text { the } \\
\text { perception } \\
\text { of teenage } \\
\text { mothers } \\
\text { regarding } \\
\text { teenage } \\
\text { pregnancy. }\end{array}$ & $\begin{array}{l}\text { Rese } \\
\text { arch } \\
\text { varia } \\
\text { ble- } \\
\text { Perce } \\
\text { ption } \\
\text { of } \\
\text { teena } \\
\text { gers } \\
\text { on } \\
\text { teena } \\
\text { ge } \\
\text { pregn } \\
\text { ancy }\end{array}$ & $\begin{array}{l}\text { Face to face } \\
\text { interview } \\
\text { with open } \\
\text { ended } \\
\text { questionnair } \\
\text { e. }\end{array}$ & $\ldots \ldots$ & $\begin{array}{l}\text { The finding of } \\
\text { this study } \\
\text { shown that } \\
\text { teenagers } \\
\text { perceived } \\
\text { teenage } \\
\text { pregnancy as } \\
\text { something } \\
\text { which was } \\
\text { unplanned and } \\
\text { teenage } \\
\text { pregnancy } \\
\text { associated } \\
\text { with individual } \\
\text { characteristics } \\
\text { such as } \\
\text { knowledge, } \\
\text { maturity and } \\
\text { age at first } \\
\text { intercourse. }\end{array}$ & $\begin{array}{l}\text { Teenage } \\
\text { pregnancy } \\
\text { based on } \\
\text { maturity } \\
\text { and } \\
\text { education. }\end{array}$ \\
\hline 3. & $\begin{array}{l}\text { Adolescent } \\
\text { Perceptions } \\
\text { of teen }\end{array}$ & $\begin{array}{l}\text { Newyark, } \\
\text { 22-Jan- } \\
2008\end{array}$ & $\begin{array}{l}\text { To } \\
\text { investigate } \\
\text { teens' }\end{array}$ & $\begin{array}{l}\text { Rese } \\
\text { arch } \\
\text { varia }\end{array}$ & $\begin{array}{l}\text { Focus group } \\
\text { interview }\end{array}$ & $\begin{array}{l}40 \\
\text { minutes }\end{array}$ & $\begin{array}{l}\text { The finding of } \\
\text { this study in } \\
\text { which teen's }\end{array}$ & $\begin{array}{l}\text { Adolescent } \\
\text { mothers } \\
\text { have }\end{array}$ \\
\hline
\end{tabular}




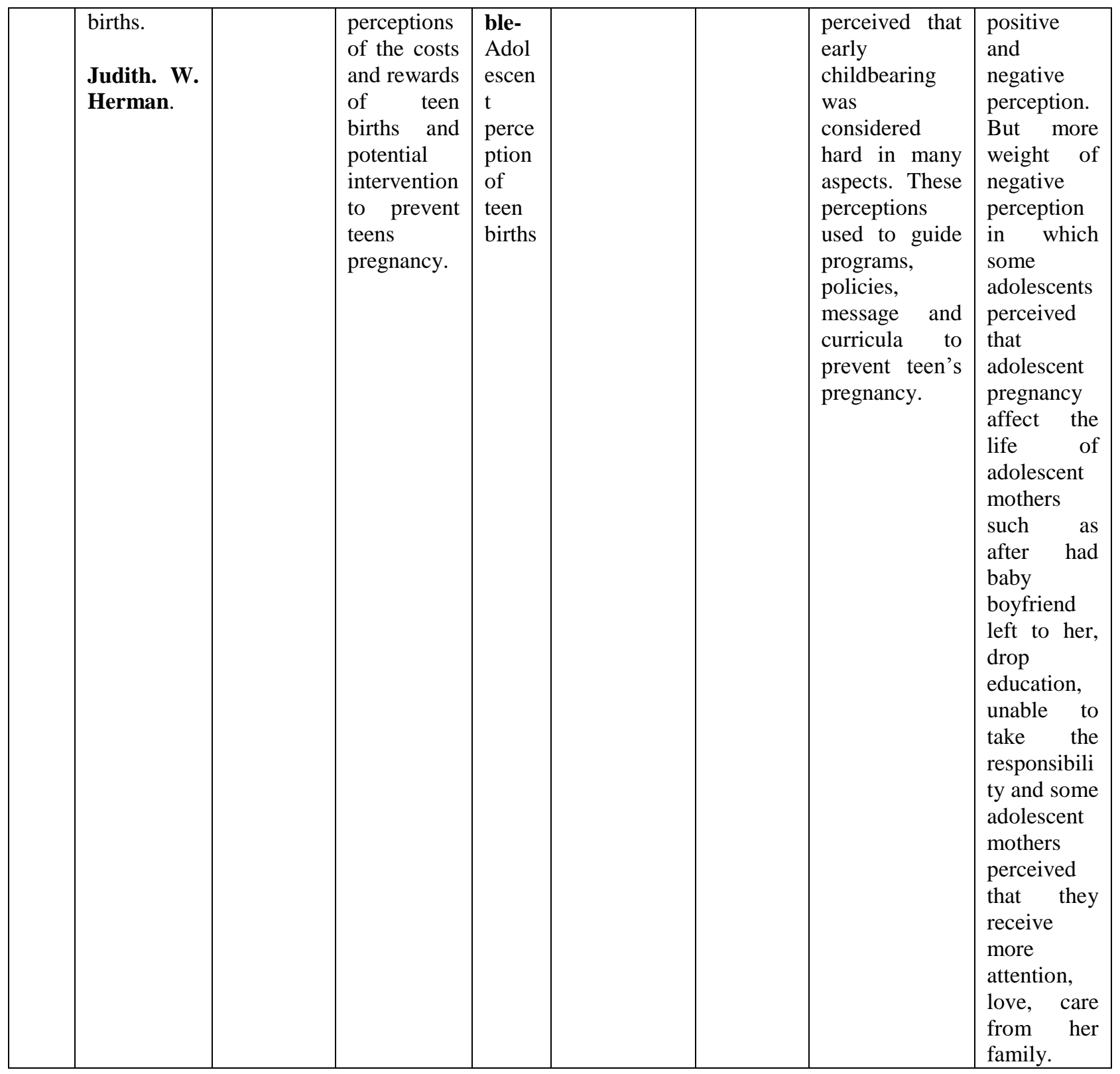

\begin{tabular}{|c|c|c|c|c|c|c|c|c|}
\hline 4. & $\begin{array}{l}\text { Knowledge, } \\
\text { attitudes and } \\
\text { perceptions } \\
\text { about unsafe } \\
\text { sex and } \\
\text { teenage and } \\
\text { pregnancy. } \\
\text { Alick } \\
\text { Austine } \\
\text { kayange }\end{array}$ & $\begin{array}{l}\text { Tanzania, } \\
\text { may } 2015\end{array}$ & $\begin{array}{l}\text { To explore } \\
\text { the } \\
\text { knowledge, } \\
\text { attitude } \\
\text { and } \\
\text { perception } \\
\text { about } \\
\text { unsafe sex } \\
\text { and } \\
\text { teenage } \\
\text { pregnancy } \\
\text { among } \\
\text { adolescent. }\end{array}$ & $\begin{array}{l}\text { Research } \\
\text { variable- } \\
\text { Knowledge, } \\
\text { attitude and } \\
\text { perception } \\
\text { about unsafe } \\
\text { sex and } \\
\text { teenage } \\
\text { pregnancy. }\end{array}$ & $\begin{array}{l}\text { In-depth } \\
\text { interview }\end{array}$ & - & $\begin{array}{l}\text { The } \\
\text { study } \\
\text { found } \\
\text { that } 18 \\
\text { out of } 20 \\
\text { responde } \\
\text { nts had } \\
\text { understan } \\
\text { ding of } \\
\text { unsafe } \\
\text { sex and } \\
\text { teenage } \\
\text { pregnanc } \\
\text { y but } \\
\text { more }\end{array}$ & $\begin{array}{l}\text { Adolesce } \\
\text { nt } \\
\text { perceive } \\
\text { d that } \\
\text { who } \\
\text { engaged } \\
\text { with } \\
\text { unsafe } \\
\text { sex } \\
\text { caused } \\
\text { teenage } \\
\text { pregRäix } \\
\text { y. }\end{array}$ \\
\hline
\end{tabular}




\begin{tabular}{|c|c|c|c|c|c|c|c|c|}
\hline & & & & & & & $\begin{array}{l}\text { than half } \\
\text { did not } \\
\text { understan } \\
\text { d and } \\
\text { unable to } \\
\text { relate } \\
\text { unsafe } \\
\text { sex to } \\
\text { both } \\
\text { teenage } \\
\text { pregnanc } \\
\text { y and } \\
\text { HIV } \\
\text { infection. } \\
\text { Adolesce } \\
\text { nts who } \\
\text { were } \\
\text { living } \\
\text { with } \\
\text { HIV/AD } \\
\text { S, they } \\
\text { need } \\
\text { repetitive } \\
\text { and } \\
\text { comprehe } \\
\text { nsive } \\
\text { reproduct } \\
\text { ive health } \\
\text { education }\end{array}$ & \\
\hline 5. & $\begin{array}{l}\text { Attitudes, } \\
\text { perceptions } \\
\text { and } \\
\text { understanding } \\
\text { amongst } \\
\text { teenagers } \\
\text { regarding } \\
\text { teenage } \\
\text { pregnancy, } \\
\text { sexuality and } \\
\text { contraception. } \\
\text { Kanku T. }\end{array}$ & $\begin{array}{l}\text { Taung } \\
\text { (South } \\
\text { Africa),2009 }\end{array}$ & $\begin{array}{l}\text { To } \\
\text { understand } \\
\text { the attitude } \\
\text { and } \\
\text { perception } \\
\text { of teenage } \\
\text { mothers } \\
\text { regarding } \\
\text { teenage } \\
\text { pregnancy. }\end{array}$ & $\begin{array}{l}\text { Research } \\
\text { variable- } \\
\text { Attitude and } \\
\text { perceptions } \\
\text { amongst } \\
\text { teenagers } \\
\text { regarding } \\
\text { teenage } \\
\text { pregnancy, } \\
\text { sexuality and } \\
\text { Contraception } \\
\text { - }\end{array}$ & $\begin{array}{l}\text { In depth } \\
\text { interview } \\
\text { and focus } \\
\text { group } \\
\text { discussion }\end{array}$ & $\cdots$ & $\begin{array}{l}\text { Result } \\
\text { shown of } \\
\text { this study } \\
\text { that most } \\
\text { of the } \\
\text { teenagers } \\
\text { perceived } \\
\text { falling } \\
\text { pregnant } \\
\text { as a } \\
\text { negative } \\
\text { event } \\
\text { which } \\
\text { cause } \\
\text { such as } \\
\text { unemplo } \\
\text { yment, } \\
\text { loss of a } \\
\text { boy } \\
\text { friend, } \\
\text { blame } \\
\text { from } \\
\text { friends } \\
\text { and } \\
\text { family } \\
\text { members, }\end{array}$ & $\begin{array}{l}\text { Liberal } \\
\text { attitude } \\
\text { towards } \\
\text { casual } \\
\text { sex, } \\
\text { alcohol } \\
\text { consump } \\
\text { tion and } \\
\text { fear use } \\
\text { of } \\
\text { contrace } \\
\text { ptive } \\
\text { methods. }\end{array}$ \\
\hline
\end{tabular}




\begin{tabular}{|c|c|c|c|c|c|c|c|c|}
\hline & & & & & & & $\begin{array}{l}\text { feeling } \\
\text { guilty, } \\
\text { difficulty } \\
\text { at school, } \\
\text { risk of } \\
\text { HIV }\end{array}$ & \\
\hline 6. & $\begin{array}{l}\text { Experience of } \\
\text { pregnancy } \\
\text { among } \\
\text { Iranian } \\
\text { adolescents. } \\
\\
\text { Nahid } \\
\text { Dehghan } \\
\text { Nayeri, } \\
\text { Mansooreh } \\
\text { Tajvidi }\end{array}$ & $\begin{array}{l}\text { Iranian and } \\
2014\end{array}$ & $\begin{array}{l}\text { To explore } \\
\text { the } \\
\text { experience } \\
\text { of } \\
\text { teenagers } \\
\text { regarding } \\
\text { teenage } \\
\text { pregnancy. }\end{array}$ & $\begin{array}{l}\text { Research } \\
\text { variable- } \\
\text { Experience of } \\
\text { pregnancy } \\
\text { among Iranian } \\
\text { adolescent. }\end{array}$ & $\begin{array}{l}\text { Deep and } \\
\text { semi - } \\
\text { structured } \\
\text { Interview } \\
\text { with open } \\
\text { ended } \\
\text { questionn } \\
\text { aire. }\end{array}$ & $\begin{array}{l}30 \\
\text { an } \\
\text { d } \\
45 \\
\text { mi } \\
\text { nut } \\
\text { es }\end{array}$ & 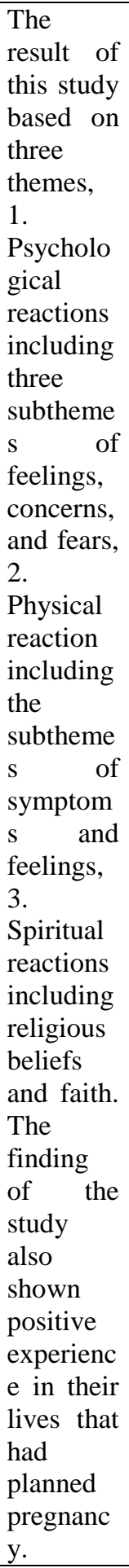 & $\begin{array}{l}\text { Teenage } \\
\text { mothers } \\
\text { said that } \\
\text { in their } \\
\text { family } \\
\text { sister } \\
\text { and } \\
\text { mother } \\
\text { got } \\
\text { married } \\
\text { as } \\
\text { teenage } \\
\text { and got } \\
\text { pregnant } \\
\text { as } \\
\text { teenage } \\
\text { Teenage } \\
\text { mother } \\
\text { said that } \\
\text { she did } \\
\text { not } \\
\text { intereste } \\
\text { d in } \\
\text { higher } \\
\text { educatio } \\
n \text { hence } \\
\text { she got } \\
\text { pregnant } \\
\text { as } \\
\text { teenage. }\end{array}$ \\
\hline
\end{tabular}




\section{Results:-}

In this review 6 studies selected which results explained below:-

1. The first category of result were found that teenager's had negative attitudes toward teenage pregnancy and supportive attitudes toward abortion. Girls were perceived as more obliged than boys in taking responsibility for contraceptive uses and avoidance of pregnancy (Extrand. Larsson. et.al, 2004).

2. The second category of result were found that teenagers perceived teenage pregnancy as something which was unplanned and teenage pregnancy associated with individual characteristics such as knowledge, maturity and age at first intercourse (Richter, et.al).

3. The third category of result found in which teen's perceived that early childbearing was considered hard in many aspects. These perceptions used to guide programs, policies, message and curricula to prevent teen's pregnancy (Herman).

4. The fourth category of result found that 18 out of 20 respondents had understanding of unsafe sex and teenage pregnancy but more than half did not understand and unable to relate unsafe sex to both teenage pregnancy and HIV infection. Adolescents who were living with HIV/AIDS, they need repetitive and comprehensive reproductive health education (Kayange).

5. The fifth category of result found that most of the teenagers perceived falling pregnant as a negative event which cause such as unemployment, loss of a boy friend, blame from friends and family members, feeling guilty, difficulty at school, risk of HIV (Kanku .T,2009).

6. The last category of result found which based on three themes, 1. Psychological reactions including three subthemes of feelings, concerns, and fears, 2. Physical reaction including the subthemes of symptoms and feelings, 3. Spiritual reactions including religious beliefs and faith. The finding of the study also shows positive experience in their lives that had planned pregnancy. (Nahid, et.al, 2014)

Analysis of the results can be mainly categorized in four themes:

Peer Pressure:-

A participant said that:-

"......Girls pressurized by their friends, telling them if they stay vergins they will get sick. So they end up having sex."

Education:-

A participant said that:-

“..Being a pregnant I don't think is a good idea especially if you are a teenager still at school. You start becoming tired after having school...”

One teen said that:-

"Going to school and having a baby .....that's stress...."

WORK:-

A teen parent stated :-

"I don't get sleep.... I go to work, school and take care of my baby...it's a mess."

Impact On Self:-

One mother noted that:

"Parenting makes you grow up fast."

\section{Discussion:-}

The finding of the present review shows that most adolescent mothers perceived falling in pregnancy as a negative event which result arise such as unemployment because teenage mother unable to take both responsibility as teenage ,they did not have that much physical strength and matured to take responsibility of family and not complete their education. Teenage mothers guilty after conceiving as teenage, difficult to attend school, complication during pregnancy and delivery, risk of HIV and secondary infertility in case of any abortion done previously. In few studies some adolescent mothers have positive and negative aspects regarding teenage pregnancy. Some adolescent mothers said that they receive more attention, love, care from her family after pregnancy. 


\section{Limitations:-}

The search that was carried out was within a publication period of 2005-2015. It included articles that were free to be accessed and in full text. In this review age criteria of participants from 15-19 years. These review of literature searched by databases such as EBSCO, DELNET, Pub Med.

\section{Conclusion:-}

Teenage pregnancy which is caused by poor sexual relationship between partners, negligence in use of contraceptives. It harms to the teenage mothers during their pregnancy because they face many problems such as emotionally weak, psychological disturbances, poor health status which affect the health of mother as well as baby. To prevent all these condition by giving information regarding their lifestyles, contraceptive uses, related to teenage pregnancy educate the teenagers. After pregnancy to make strong teenage mothers by providing health awareness programme. Teenage pregnancy can prevent by improve the level of education.

\section{Refrences:-}

1. Billings.(2007). Teenage parents' experiences of parenthood and views of family support services in Kent. Service user report.

2. Bonnie. (2009). Teen pregnancy prevention programme: Teens attitude towards sexuality.

3. Bowman. (2013). From her perspective: reflections of teenage pregnancy and parenthood. Master of social work clinical research papers.

4. Edzisani.(2009), "Psychological impact of teenage pregnancy on pregnant teenagers.

5. Judith, Herman. (2008). Adolescent perception of teen births.

6. Kanku.T. (2010). Attitude, perceptions and understanding amongst teenagers regarding teenage pregnancy, sexuality and contraception in Taung. Division of family medicine and primary care. 52(6), 563-572.

7. King . Teenage Sex: A study of male and female teenagers' attitudes toward teen sex and teen pregnancy.

8. Lebese, Maputle, Chauke, Mabunda. Knowledge and attitudes and perception of students on teenage pregnancy: a case study of rural based university students in South Africa. Department of advance nursing. Department of public health.

9. Maria, Margareta, Louise.(2005). Swedish teenager perceptions of teenage pregnancy, abortion, sexual behaviour and contraceptive habits: a focus group study among 17 years old female high school students. Department of women's and children's health and department of public health and caring sciences.84, 980-986.

10. Nahid.( 2014).Experience of pregnancy among Iranian adolescent: a qualitative study. Iranian journal of nursing and midwifery research. 19(7), S7-S12 .

11. Nimmie.( 2015). A qualitative study exploring the experiences of African Australian teenage mothers in greater Melbourne, Australia.

12. Sodi. Egnes. Psychological impact of teenage pregnancy on pregnant teenagers. Thesis and Dissertation(psychology).

13. Spear.(2003).Qualitative research on adolescent pregnancy: A descriptive review and analysis. Journal of pediatrics nursing. 18(6).

14. Sunita, Walter.(2007). Knowledge and perceptions about sexually transmitted disease: A qualitative study among adolescent students in Uganda. Journal of health population and nutrition. 25(3), 319-327.

15. Vo. Pregnant and parenting teens' attitudes toward pregnancy and motherhood and their perceptions of social support. Retrospective Thesis and Dissertations.

16. Wahn. (2007) Teenage childbearing in Sweden. Department of women and child health division of reproductive and Perinatal health care.

17. Watts, Liamputtong, et.al. A qualitative study exploring the experiences of African Australian teenage mothers in greater Melbourne, Australia. 